Удк 316.4.051.62

\title{
КОЛЛЕКТИВНАЯ ИСТОРИЧЕСКАЯ ПАМЯТЬ: ОСНОВАНИЯ ВЫДЕЛЕНИЯ ПОНЯТИЯ И РОЛЬ В СОВРЕМЕННОЙ КУЛЬТУРЕ
}

\author{
Корнющенко-Ермолаева Наталия Сергеевна, \\ nskorn@yandex.ru
}

Томский государственный университет систем управления и радиоэлектроники, Россия, 634050, г. Томск, пр. Ленина, 40

Корнющенко-Ермолаева Наталия Сергеевна, старший преподаватель кафедры философии и социологии Томского государственного университета систем управления и радиоэлектроники.

\begin{abstract}
Актуальность исследования: понятие «коллективная историческая память» вызывает множество разногласий, связанных с его содержанием и употреблением. Статья посвящена проблеме использования концепта «коллективная историческая память» и анализу оснований для его выделения в качестве понятия, которое имеет свое смысловое содержание и существенные признаки. В работе исследовались роль и место концепта в современной культуре. Цель состоит в том, чтобы обосновать смысловое содержание и существенные признаки концепта «коллективная историческая память», показать, что оно может использоваться в качестве самостоятельного понятия. Как смысловой конщепт данное понятие не подменяет другие, обладает теоретической и эвристической ценностью. Коллективная историческая память - это ментальная способность социальных групп и нации в процессе коллективного запоминания и забвения символически реконструировать значимые исторические события, придавая им определенную ценностную трактовку. В статье выявлены существенные отличия коллективной исторической памяти от идеологии, определен принцип комплементарности как принцип, описывающий специфику взаимодействия коллективной исторической памяти с исторической наукой, указаны существенные отличия в содержании понятий «историческое сознание» и «коллективная историческая память», обозначены причины, по которым эти понятия не могут выступать как синонимы. Методы: теоретикометодологической основой выступают теории памяти как социокультурного феномена (М. Хальбвакса, П. Нора, П. Рикера, А. Ассман и др.), концепции, посвященные взаимоотношениям коллективной исторической памяти с идеологией, исторической наукой и историческим сознанием (А. Альтюссера, С. Жижека, А.В. Рубцова, Х. Вельцера, Дж. К. Олика и др.). Выводы: обосновывается эвристическая ценность понятия «коллективная историческая память». Раскрываются его смысловое содержание и внутренние противоречия, приводящие к терминологической путанице в социальнофилософском научном дискурсе. Понятие «коллективная историческая память» обладает теоретической ценностью, поскольку описывает уникальный феномен - фундаментальную способность социальных групп и нации в целом сохранять и реконструировать воспоминания о совместном историческом опыте.
\end{abstract}

Ключевые слова: Коллективная историческая память, политическая идеология, история, историческое сознание, национальная идентичность, официальная память.

Коллективные представления об историческом прошлом и их оценка являются неотъемлемой частью любой культуры. Осуществляя трансляцию исторического опыта от поколения к поколению, историческая коллективная память является основой для формирования и сохранения национальной идентичности, особенно в моменты серьезных социальных потрясений и трансформаций. Коллективные воспоминания, с одной стороны, представляют собой основу для создания идеи национального единства и чув- 
ства общности, с другой - выступают источником для критического представления нации о самой себе. Репрезентация нацией своего прошлого и его этические коннотации являются неким императивом, который в значительной степени выстраивает вектор ее будущего развития.

Проблематизация коллективной исторической памяти, выделение её в качестве значимого объекта философской рефлексии позволяют осуществить рельефное выделение её исторических трансформаций, определяющих моментов её использования. Современные стратегические планы по сохранению и спасению прошлого возникают не спонтанно, из естественного желания помнить о каких-то знаковых событиях, а из ясного осознания хрупкости культурных традиций и ценностей, которые необходимо сохранить по причине угрозы их исчезновения. Таким образом, активное стремление к сохранению исторической памяти вызвано осознанием ускорения деструктивных процессов старения и разрушения традиций, характерное для общества постмодерна. Прошлое, реконструированное исторической памятью социальных групп и отдельных индивидов, оказывается значительно более сложным и противоречивым феноменом, нежели объективные данные исторической науки, поэтому можно с уверенностью говорить о парадоксальности этого феномена.

Несмотря на то, что понятие «коллективной исторической памяти» основательно вошло в социально-философский и политический дискурс во второй половине XX в., можно обнаружить достаточно много неопределенностей и разногласий, связанных с его содержанием и использованием. С одной стороны, это понятие широко используется как в повседневном, так и в научном и политическом языке, с другой - в социальнофилософском дискурсе присутствует скептическое отношение к его употреблению. Отдельные исследователи объявляют это понятие метафорой, фикцией или бессмысленной конструкцией, поэтому становится актуальным ответить на вопросы о содержании и границах этого понятия. Кроме этого, стоит отметить, что в современном дискурсе понятие «память» начинает использоваться различными представителями социальногуманитарного знания как составная часть термина, с которой образовываются сложносоставные лексемы, такие как «социальная память», «политическая память», «культурная память», «официальная память», «коллективная», «автобиографическая» и «историческая память». Границы и точки пересечения этих понятий четко не установлены, и это приводит к терминологической путанице. Поэтому становится актуальным вопрос о соотношении и пересечении этих понятий.

Важно подчеркнуть тот факт, что современные тенденции, связанные, с одной стороны, с мемориальными практиками, с другой - с формированием идеологических конструктов, в которых память доминирует над историей, вызывают опасения и тревогу у научного и философского сообщества. Профессиональные историки неоднократно обращали внимание на то, что государство и СМИ провоцируют ситуации «нарушения режима доверия» исторической науке и историкам, когда очевидцам и участникам событий верят больше, чем историкам, которые стремятся сформировать объективную и критическую точку зрения на события прошлого. Кроме этого, вызывают опасения дихотомии «история/идеология», «история/память», существование которых в современном дискурсе латентно указывает на снижение ценности критической инстанции в мемориальных практиках, во многом противостоящей эмоциональному характеру требований, связанных с исторической памятью социальных групп и национальных меньшинств. В сообщениях СМИ и повседневной практике сегодня можно наблюдать за негативной, теневой стороной мемориальной революции, которая проявляет себя в «войнах памяти», начиная от «войны памятников и захоронений» и заканчивая серьезными 
этнополитическими конфликтами. Коллективные воспоминания о своем прошлом, с одной стороны, жизненно необходимы для сохранения единства нации, с другой - содержат в себе потенциальную опасность по созданию агрессивных мифов, которые провоцируют межгосударственные и межнациональные конфликты и насилие. Коллективная историческая память может привести «...к войне, а не к миру ...и к решимости скорее отомстить, чем посвятить себя тяжелой работе прощения» [1, с. 27]. Память может не только разжечь насилие, но и продлить его. Как мы видим, тема коллективной исторической памяти порождает множество вопросов, которые попадают в поле философского осмысления.

Исследование феномена исторической памяти имеет не только теоретическое, но и практическое значение. Необходимо учитывать, что национальная память сохраняет воспоминания не только о триумфальных победах и тяжелых поражениях, но и о событиях, которые вызывают чувство коллективной вины и позора нации. И те, и другие в равной степени могут формировать представление нации о самой себе, укреплять или разъединять национальную сплоченность, способствовать созданию национальной идеи, консолидирующей нацию, либо разрушать идею, не предлагая весомой замены. Особенностью мемориальных конструктов исторической памяти, закрепляющих преимущественно свои победы и исключительно поражения соседей, является способность продлевать исторические конфликты за пределы своего времени. Знание о том, каким образом изменения политических условий может вызвать периоды политической нестабильности, позволяет прогнозировать события и влиять на них.

Формирование концепта «коллективной исторической памяти» начинается в процессе исследований массовых представлений о прошлом, которые привлекли внимание философов и социологов в середине XX в. Изучение темы «коллективной исторической памяти» принято начинать с работ французского социолога М. Хальбвакса, который первым изучил влияние социальных факторов на индивидуальную память. Позже он ввел понятие «коллективная памяти», вокруг которого развернулась напряженная дискуссия.

Оппонентами и критиками концепта коллективной памяти М. Хальбвакса становятся американский философ С. Зонтаг, немецкий историк и теоретик исторической науки Р. Козеллек, венский философ Р. Бургер, немецкий историк религии и культуры Я. Ассман, голландский философ Ф. Анкерсмит и др. Они выступают против признания коллектива субъектом памяти и употребления (пусть и метафорического) понятий «коллективная память» и «память нации».

Становится очевидным, что тема коллективной исторической памяти носит междисциплинарный характер. Исследованием содержания понятия «коллективная историческая память», скрытых в нем противоречий, в современном гуманитарном дискурсе, в равной степени интересуются как философы, так и социологи, политологи и культурные антропологи. Однако, несмотря на значительные достижения в области исследования исторической памяти, проблема содержания этого понятия и его границ остается недостаточно изученной. Вопрос заключается в том, что такое коллективная историческая память: это обыденные представления о прошлом разных социальных групп и нации в целом или целенаправленный динамический процесс, организованный со стороны государства, социальной и политической среды, преследующий конкретные цели по манипулированию массовым сознанием?

Основная идея данной статьи состоит в том, что понятие «коллективной исторической памяти» имеет свое смысловое содержание и существенные признаки, может использоваться в качестве самостоятельного понятия. Как смысловой концепт оно не подменяет другие понятия, обладает теоретической и эвристической ценностью. Кол- 
лективная историческая память - это способность социальных групп и нации в целом в процессе двух взаимосвязанных механизмов коллективного запоминания и забвения символически реконструировать социально значимые исторические события, придавая им определенную ценностную трактовку.

Основные претензии к употреблению и содержанию понятия «коллективная историческая память» можно свести к описанным ниже концептуальным положениям.

Во-первых, противники употребления понятия выступают против признания коллектива субъектом памяти. Воспоминания, по их мнению, принадлежат только индивиду и исчезают со смертью их носителя. На этом основании они утверждают, что понятия «коллективная память» и «память нации» могут использоваться только как метафоры. Я. Ассман, несмотря на то, что его теория культурной памяти выстраивалась на подобном методологическом фундаменте, неоднократно в своей книге «Культурная память» высказывался против признания коллектива субъектом памяти и возможности использования в научном дискурсе понятий «групповая память» и «память нации» [2]. Во-вторых, критики концепта «коллективная историческая память» солидарны в том, что «...такого явления, как коллективная память, не существует» [3]. С. Зонтаг в книге «Когда мы смотрим на боль других» приходит к умозаключению: «То, что мы зовем коллективной памятью, - на самом деле не память, не воспоминание, а условность, конвенция, соглашение $<$...>» [3].

В-третьих, эти мыслители утверждают, что во второй половине XX в. концепт «коллективная память» заменил собой понятие «идеология», т. е. в современном дискурсе произошла подмена понятий, объясняемая «сменой парадигмы от критики идеологии к коллективной памяти» [4, с. 28].

В-четвертых, в связи с появлением понятия «коллективная историческая память» актуализировалась проблема взаимоотношений между исторической наукой и коллективной памятью. И, наконец, в-пятых, встал вопрос о замене основополагающего понятия истории «историческое сознание» понятием «коллективная историческая память». Таким образом, можно сделать вывод, что границы понятия «коллективная историческая память» не установлены, а концепт «историческая коллективная память» используется в разных смыслах, включая метафорические. Встает вопрос об условности этого конструкта. В связи с этим необходимо прояснить смысловое содержание и теоретическую ценность этого понятия, последовательно ответить на возражения и критические замечания оппонентов, которые критически высказываются по отношению к использованию этого понятия в социально-философском дискурсе. С этой целью будет предпринята попытка разграничить понятия «коллективная историческая память» и «политическая идеология», выявив их существенные отличия; определить принцип взаимодействия коллективной исторической памяти с исторической наукой; развести понятия «историческое сознание» и «коллективная историческая память», показав по каким причинам они не могут быть синонимичными.

В данном исследовании используется сложносоставное понятие «коллективная историческая память», которое требует пояснения, поскольку содержит в себе терминологическую трудность, связанную с расширением объема понятия. В свое время, когда М. Хальбвакс ввел в гуманитарный дискурс понятие «коллективная память», вопрос о том, является ли коллективная память исторической, оказался открытым и потребовал своего прояснения. Французский социолог не использовал предикаты «коллективная» и «историческая» как тождественные. Он называет коллективную память исторической на том основании, что индивид всегда принадлежит какому-то коллективу (семье, нации, этносу, социальной группе), у которого есть своя история - череда 
внешних событий, временные рамки которых гораздо шире времени жизни одного конкретного индивида. Любой человек является частью социального целого, и история коллектива пересекается с его личной историей. Когда мы обращаемся к прошлым событиям нашей жизни, у нас всегда есть возможность распределить их по единицам коллективного времени, которые мы находим вне себя и которые извне накладываются на все индивидуальные памяти именно потому, что они не происходят ни из одной из них. «Мы можем привязать различные фазы нашей жизни к событиям национального масштаба лишь задним числом. События и даты, составляющие материал групповой жизни для индивида, могут быть только внешними знаками, к которым он может обращаться, лишь покидая рамки своего «Я». Личные воспоминания первичны, на них накладываются коллективные воспоминания, обеспечивая нам удобный и надежный контроль над первыми. Иначе наша память действовала бы впустую. Индивидуальная память опирается не на выученную, а на прожитую историю» [5, с. 34].

Из концепции М. Хальбвакса становится очевидным, что главным референтом исторической памяти является нация, а субъектами (носителями) коллективной памяти выступают социальные группы. По мнению философа, индивидуальная и коллективная память прирастают историческим прошлым. «Если под исторической памятью мы понимаем ряд событий, воспоминания о которых хранит национальная история, то не она ли, не ее ли рамки являются основной частью того, что мы называем коллективной памятью?» [5, с. 42]. Таким образом, понятие «исторической памяти» шире понятия «коллективная память», но в идеале историческая память растворяется в коллективной, тем самым расширяя её временной горизонт.

Одним из ключевых моментов, приводящим к трудностям изучения исторической коллективной памяти, является её социальная дифференциация. Коллективных памятей столько, сколько социальных групп, к которым принадлежит индивид. Историческая коллективная память закрепляется как национальная память или память отдельных социальных групп, только получив соответствующее институциональное оформление.

В современных концепциях доминирует понимание коллективной исторической памяти как социального конструкта воспоминаний о прошлом и деконструкции выполнивших свои функции мифов, а не реконструкции, как это было в начале появления понятия в концепциях М. Хальбвакса и П. Нора. Прошлое конструируется человеком или социальной группой в зависимости от его актуальных потребностей и возможностей воображения. Коллективную память нельзя рассматривать как сумму индивидуальных воспоминаний и конкретных деталей происшедшего, это всегда совершенно иначе выстроенные «реконструкции» и «конструкции» исторических процессов и событий.

Коллективная память фиксирует и формирует образы исторических событий в форме различных культурных стереотипов, символов и мифов. В ней можно структурно выделить три уровня:

1. Живая коммуникативная память, которая основана на устной традиции, возникающей из пережитого опыта и культивации воспоминаний в интерактивном контексте межличностных взаимодействий в повседневной жизни. Это своего рода «живые воспоминания». Их продолжительность ограничивается взаимодействием трех-четырех поколений (дети-отцы-деды-прадеды).

2. Функциональная (или символическая) память, которая обеспечивает существование воспоминаний через повторяемость символических практик (традиции, ритуалы, праздники). Она выходит за рамки опыта отдельных людей и социальных групп и выражается в памятных местах, датах, церемониях (праздниках), в письменных, изобразительных и монументальных памятниках. Функциональная память выходит на уровень «память нации». 
3. Накопительная память, которая действует благодаря материальным репрезентациям (книги, фильмы, архивы, музеи, образование).

Возникает закономерный вопрос: на каком основании противники концепта «коллективной исторической памяти» настаивают на том, что это понятие появляется в политико-философском дискурсе исключительно с целью подмены им понятия «идеологии»? Почему «ряд критиков подозревают, что коллективная память - это убогое замещение таких давних понятий, как политическая традиция или миф» [6, с. 23]? Подобное утверждение связано с тем, что в XX в. произошло кардинальное изменение способов функционирования идеологии, что позволило ей действовать «анонимно». В связи с этим некоторые обществоведы начали говорить о «конце» идеологии (Д. Белл, Ж. Фурастье, С. Липсет). Появились концепции деидеологизации. Однако стоит заметить, что роль идеологии в обществе не снизилась. Идеологическое сохраняется, но в новых формах организации. Претерпел серьезные изменения сам способ её существования. «Идеология была демонтирована более как официальная риторика, система институтов и символов, чем как глубоко укорененная сборка идей и представлений» [7, с. 107], и именно этот момент необходимо учитывать, анализируя взаимоотношения политической идеологии и коллективной исторической памяти.

Одна из существенных характеристик, позволяющая говорить о пересечении понятий «идеология» и «коллективная память», - это общность их структур. В современном философском дискурсе все больше исследователей начинают анализировать идеологию через понятие бессознательного (К. Манхейм, Л. Альтюссер и др.). Идеологические конструкции структурно включают как осознаваемый, так и бессознательный уровни мотивации, поэтому продукты идеологии являются выражением одновременно двух интенций [8]. Несмотря на то, что многие исследователи идеологических теорий единодушны во мнении, что любая идеология логична, часть идеологического содержания выходит за рамки рациональности и является отражением бессознательного. «Идеология, таким образом, есть выражение отношения людей к их «миру», т. е. (сверхдетерминированное) единство реального и воображаемого отношений к реальным условиям их существования. В идеологии реальное отношение неизбежно завуалировано (investi) отношением воображаемым, которое скорее выражает некую волю (консервативную, конформистскую, реформистскую или революционную), надежду или ностальгию, чем описывает какую-то реальность» [9, с. 331]. Апологеты той или иной идеологии принимают её идеи не столько на рациональных основаниях, сколько эмоционально заряжаются её убеждениями и ценностями. В содержании идеологических представлений и образов обязательно имеют место аффективные, иррациональные компоненты. Именно они вызывают глубокий эмоциональный отклик у населения, поскольку большинство людей лучше поддается не воздействию рациональных доводов, а эмоционально заряженных лозунгов и идей. «Идеология сплошь и рядом эффективнее воздействует именно через образы, через управление настроениями и страстями, включая ненавязчивые подсказки действий» [7, с. 119], она глубоко бессознательна даже тогда, когда она принимает рефлексивные формы.

В бессознательных структурах идеологии могут уживаться противоречивые и взаимоисключающие представления. Любая идеология действительно успешна ровно в той мере, в какой она не позволяет увидеть противоречия между предлагаемыми ею конструкциями и действительностью, когда она задает сам модус действительного повседневного опыта» [10, с. 28]. Её воздействие на коллективное бессознательное происходит посредством индоктринации, целенаправленного внушения. Готовые идеологические стереотипы заражают мотивацией к социальному действию и принимаются не критическим коллективным сознанием на веру. 
Историческая коллективная память - это особый вид человеческой памяти, содержащий безличные воспоминания индивида как члена социальной группы о национальных исторических событиях. Как сложное динамическое явление, коллективная память также имеет два уровня: сознательный и бессознательный. Ей свойственна не столько рациональная, сколько эмоциональная оценка прошлого. Именно поэтому П. Нора определяет её как память, часто «не осознающую себя» [11, с. 19]. Коллективная память, как живая динамическая система, находится в постоянном процессе эволюции. Она открыта диалектике запоминания и сохранения информации, а также амнезии, не отдавая себе отчета в своих деформациях. Коллективная память, согласно М. Хальбваксу, подвержена двойному процессу трансформации: она одновременно формируется и деформируется. На этом основании М. Хальбвакс обращает внимание, что существование коллективной памяти протекает по своим законам, которые требуют изучения. Историческая коллективная память, в отличие от идеологии, возникает тогда, когда историческое прошлое передается путем живого рассказа от представителя одного поколения другому. Этот рассказ пробуждает у представителей следующего поколения интерес к событиям, свидетелями которых они не могли быть, и позволяет преодолеть чуждость исторического прошлого. Таким образом, коллективная историческая память - это поколенческая память, она соединяет поколения, обеспечивая «переход от выученной истории к живой памяти» [5, с. 57]. Идеологические концепции создаются философами, политиками, но не народными массами.

Ключевым моментом, который указывает на пересечение понятий «историческая коллективная память» и «идеология», является то, что любая идеология, как и коллективная историческая память, связана с переосмысления исторического прошлого. Одна из функций идеологии связана с формированием ценностного отношения к знаковым для нации историческим событиям. Как писал Альтюссер, идеология может быть превращена «в орудие рефлексивного воздействия на историю» [9, с. 330].

Ретроспективный взгляд в прошлое для идеологии представляет собой в первую очередь исходный материал для конструирования своей собственной предыстории с целью обосновать закономерность своего появления. Идеологии формируют привлекательные для широких масс идеи и образы, «помещая в них, как в капсулы, наши представления о важном, значимом, и порождая таким образом циркуляцию в обществе весьма предсказуемых идей и впечатлений» [3]. Давно забытое коллективным сознанием историческое событие может быть реанимировано и использовано идеологами для своих целей. «Идеологически правильные» мертвые будут вырваны из исходного контекста: надгробия их могил будут перенесены <..> Памятники будут собраны в специальных мемориальных пространствах, эдаких «потемкинских деревнях» для мертвых, за фасадами которых не будет никакого содержания» [12, с. 175]. Таким образом, в идеологии настоящее конституирует прошлое, его оценка может меняться в зависимости от целей его использования. Из определенного видения прошлого идеология выстраивает технологии достижения будущего. Она, как правило, ориентирована на современность и обязательно футуристична.

Когда идеология действует как дискурс, поддерживающий власть, коллективная память может стать объектом манипуляции. «...Становится возможным связать явные злоупотребления памятью с последствиями искажения, имеющими место на феноменальном уровне идеологии» [13, с. 125]. В данном случае появляется опасность отождествить коллективную память с официальной памятью, которую П. Рикер определяет как «навязанную», подкрепленную самой «дозволенной» историей - историей официальной. Формирование этой памяти связано с обучением и принудительным запоми- 
нанием дат, событий и исторических лиц. Однако это преподанная история, которой обучают, а не переживают в качестве индивидуального или коллективного опыта. К принудительному запоминанию прибавляются и мемориальные церемонии, поминания, установленные общим соглашением. Таким образом, между припоминанием, запоминанием и поминанием заключается несущий в себе опасность пакт» [13, с. 125]. Таким образом, между официальной (публичной) памятью, легитимированной в обществе, и памятью приватной, сохраняемой в семьях и малых социальных группах, может иметь место противоречие, переходящее в конфликт. Публичная память формируется системой образования (преподаванием официальной истории), политикой и дидактикой мемориальных комплексов. В современных обществах можно наблюдать «конфликты воспоминаний», которые зачастую связаны с тем, что свидетели событий помнят о них не так, как о них принято говорить в официальной истории. У свидетелей, в силу удаленности события, уже сформировалось эмоционально кодированное представление, которое не может быть изменено за счет информации, полученной в настоящее время.

Одним из важных вопросов во взаимоотношениях коллективной исторической памяти и идеологии является тема искажения фактов об историческом прошлом. Искажения присутствуют как в исторической коллективной памяти, так и в идеологических конструктах. Однако механизм этих искажений различный. Идеология реконструирует исторические события исходя из тех принципов и мировоззренческих позиций, которые считает верными и не подвергает их процедуре гносеологической верификации. Как теоретическая система идеология включает в себя одновременно с достоверными знаниями об историческом прошлом и целенаправленно искаженные представления, которые смещают акценты и меняют оценки событий и деятельности политических лидеров. «Имеется в виду фабрикация таких текстов, в которых крупицы истины тонут в море сознательного обмана» [14, с. 182]. Комплекс идеологем, подкрепленных ёмкими образами прошлого, позволяет создать канал, сообщающий личность и социум, гармонизующий их отношения в рамках единства целей и задач развития. Прошлое, таким образом, становится для идеологии инструментальным, открывающим возможности для манипуляций сознанием, мотивацией и оценками широких масс.

Определенные события прошлого получают в коллективном сознании высокую «коммеморативную плотность». Она может выделять их из длинного ряда эпизодов национальной истории, придавать им особый статус символических текстов - нарративов, служащих ключом к пониманию других событий истории данного социума. Таким образом, в коллективной памяти историческое событие может превратиться в политический миф, через призму которого, как сквозь увеличительное стекло, члены данного сообщества видят настоящее и пытаются представить себе будущее. Поскольку поворотные моменты часто обретают символический смысл как знаки перемен, они скорее других трансформируются в политические мифы. Как таковые, они не только отражают социально-политические потребности социума, способствовавшие возникновению этого мифа, но сами становятся силой, формирующей эти потребности. В идеологии миф означает сознательное и целенаправленное искажение исторических фактов, в коллективной памяти миф - это взгляд на историческое событие сквозь призму национальной идентичности. В этом случае миф является аффективным усвоением нацией собственной истории и ее бессознательным искажением.

Таким образом, механизм работы коллективной памяти связан не только с сохранением воспоминаний, но и с абберациями памяти, которые приводят к бессознательным искажениям воспоминаний. В отличие от коллективной памяти, в которой происходит неосознанная абберация, в идеологии происходит сознательная фальсификация 
воспоминаний. Бессознательные искажения воспоминаний обусловлены, с одной стороны, высокой эмоциональной значимостью события, с другой - многократной повторяемостью рассказа о нем. В процессе неоднократного воспроизведения воспоминания происходят постоянные дополнения рассказа вымышленными деталями. При этом чем выше степень значимости воспоминания, тем больше оно претерпевает существенных трансформаций и дополнений. В этом и заключается парадоксальность коллективной памяти.

Процесс искажения (аббераций памяти) происходит по следующей схеме: неизменно в процессе рассказа вызванное в памяти воспоминание. Оно фиксируется в памяти каждый раз в новом качестве, обогащается новыми нюансами и корректируется в зависимости от контекста ситуации, в которой имело место. Таким образом, формула памяти может быть представлена следующим образом: воспоминание - это каждый раз событие плюс воспоминание о том, как и при каких обстоятельствах его вспоминали.

Нарративы о коллективно пережитых исторических событиях, связанных с большой степенью травматичности, обладают способностью оказывать сильное эмоциональное воздействие как на индивидуальные, так и на коллективные воспоминания, приводя их к тому стандарту, в котором их помнит большинство. Именно поэтому, когда речь идет о коллективных воспоминаниях, связанных с серьезными историческими потрясениями, можно наблюдать феномен стандартизации комплекса воспоминаний, присутствующих в социуме. Создается обманчивое впечатление, что все участники событий в этот период имели один и тот же опыт.

В процессе социальной коммуникации внутри коммеморативных сообществ происходит длительный обмен историями. Рассказы модифицируются и «переписываются» до того момента, пока у большинства членов группы не окажется идентичного набора одинаковых историй. Эти истории могут быть основаны на отдаленно схожем личном опыте, но в деталях оказываются «ложными» - сконструированными воспоминаниями, сформированными не собственным опытом, а скорее коммуникативным обменом. Чем более удалено событие, тем стабильнее и статичнее воспоминание о нем. Воспоминание удаленного во времени события имеет более завершенный характер и тем более оно отрефлексировано.

Политическая идеология и коллективная историческая память содержат в себе момент ценностного отношения к истории: оценивание исторических событий прошлого с позиции актуального настоящего. Однако различия между коллективной памятью и идеологией очевидны. Коллективная память включает в себя исторические воспоминания как о триумфальных победах нации, так и о ее постыдных поражениях, связанных с кровавым насилием, поэтому это понятие получает этические коннотации, связанные с нравственной оценкой и переосмыслением национальным самосознанием своего прошлого. Воспоминания о коллективном историческом прошлом формируются под воздействием четырех основных переживаний совместного опыта: гордости, стыда, вины и страдания.

Все идеологические системы основаны на презумпции, что обстоятельства, которые конституируют социальную реальность, могут быть изменены, если сознательно воздействовать на содержание сознания, в том числе и исторического. При формировании идеологических конструктов, необходимых для поддержания национальной идентичности и консолидации общества, исторические события порой извлекаются «из нафталина» или просто выдумываются. Эти исторические воспоминания базируются на основаниях, созданных задним числом. Иногда тот или иной исторический миф может быть абсолютно иррелевантен для коллективной идентичности. 
Таким образом, коллективная историческая память и идеология понимаются как социальные конструкты с элементом деконструкции. В отличие от идеологии, которая представляет собой относительно устойчивый и долговременный конструкт, память нестабильна, изменчива, способна к самоорганизации воспоминаний о прошлом. И идеология, и память искажают память о прошлом. Однако механизм этих искажений различный. Несмотря на то, что коллективная память формируется в том числе официальной идеологией и системой образования, по своему содержанию она чаще всего не совпадает с тем, что ей принудительно навязывается извне, поэтому между коллективной памятью и официальной идеологией может иметь место противоречие, переходящее в конфликт.

Актуализация проблемы взаимоотношений между исторической наукой и памятью была вызвана целым рядом причин, которые сформировались ко второй половине $\mathrm{XX}$ в. Во-первых, история XX в. - это история массовых катастрофических событий двух мировых войн, революций, массовых репрессий и концлагерей. Осмысление и объяснение этих событий поставили историческую науку перед вопросом о возможностях понимания и интерпретации массовых травматических событий, которых до этого не знало человечество. Во-вторых, третья коммуникативная революция (после письменности и книгопечатания) привела к изменению способов хранения информации. Это уже не только архивы и музеи, семейные хроники и мемуары. К ним добавились электронные средства фиксации, хранения и воспроизведения информации о исторических событиях, документальная кинохроника, средства массовой информации, беллетристика и символические ритуалы. Увеличилось число и многообразие свидетельств о прошлом. В-третьих, история второй половины XX в. создается уже не только усилиями профессиональных историков, людьми одного культурного слоя или интеллектуального сословия, имеющих соответствующее образование. Историческая наука вынуждена учитывать свидетельства очевидцев и участников массовых травматических событий, опыт которых требует от историка новых методов исследования [15]. Таким образом, в процессе изменения и дифференциации, которые происходили в обществе постмодерна, многократно расширялись социальные группы, которые возложили на себя миссию сохранения и воспроизведения коллективного опыта при столкновениях с банальностью массового зла. «Императив истории также вышел далеко за пределы круга профессиональных историков. Не только обычные маргиналы официальной истории оказались захвачены потребностью восстановить свое исчезнувшее прошлое. Все организованные сообщества, интеллектуальные и нет, ученые и нет, а не только этносы и социальные меньшинства, обнаруживают необходимость заняться поисками основ своей собственной организации, разысканием своих истоков» [11, с. 32].

В обществе постмодерна изменился сам процесс формирования социальных групп, который теперь происходит по принципу участия и сопричастности к какомулибо историческому событию (узники концлагерей, репрессированные, участники и ветераны войны, жители блокадного Ленинграда и т. д.). Интерес к мнениям и обыденным представлениям широких масс появляется у политической элиты, однако широким слоям населения становится не менее интересны сведения о собственных взглядах и позициях. Именно в этом причина массового распространения опросов общественного мнения начиная с 30-х гг. ХХ в.

Как считает немецкий историк и культуролог А. Ассман, основная причина обращения истории к содержанию «коллективной исторической памяти» и постановка вопроса о их соотношении связаны с тем, что «поколение очевидцев тяжелейших в анналах человеческой истории преступлений сейчас постепенно уходит из жизни» [4, с. 29], 
поэтому успеть зафиксировать эти свидетельства становится особенно актуальной задачей для историков. Самим жертвам массовых драматических событий кажется, что в отношении тех исторических ситуаций, участниками и очевидцами которых они были с течением времени, возникла угроза забвения, если не сознательного, то связанного со сменой поколений и ослаблением усилий по сохранению этого травматического опыта. По этой причине резко возросла активность носителей памяти и интенсивность действий со стороны историков по запечатлению их опыта.

Если обратиться к истории взаимоотношений истории и памяти, можно обнаружить, что в древности эти феномены не противостояли друг другу, а пересекались. «Для всех более ранних форм историописания характерно то, что они сознавали себя как разновидность воспоминания, как сохранение памяти» [4, с. 43]. Слово «история» означает и «то, что случилось», т. е. событие, и «рассказ о том, что случилось», который многократно воспроизводится очевидцами и свидетелями события и, постепенно обрастая подробностями и деталями, трансформируется в исторический миф. Разделение памяти и истории произойдет только в XIX в. Это время официально зафиксировано как дата возникновения исторической науки в качестве профессионального дискурса и удела образованной элиты. Именно в это время память и история «открыли друг в друге свою противоположность» [4, с. 43]. В процессе того, как историческая наука соединяется с метаперспективой и претендует на статус универсального и объективного знания, она все больше удаляется от памяти.

В историографии второй половины XX в. произошел так называемый «мемориальный поворот», в результате которого перед историками встал вопрос об изучении массовых обыденных представлений о прошлом, т. е. вопрос об изучении коллективной исторической памяти. Как заметил французский историк П. Нора, «проблема памяти поднимает сегодня перед историографией вопросы, которые прошлое поколение связывало с ментальностью» [11, с. 47]. Это привело не только к стиранию границы между созданием профессионального и массового исторического знания, но и к трансформации одной из главных функций исторической науки, связанной с увековечиванием настоящего. В обществе постмодерна она приобретает новое качество и несравненно больший масштаб, поскольку историк встает перед необходимостью выполнения особой социальной миссии - произвести отбор, сортировку и выбор способа хранения, подлежащего увековечиванию исторического материала.

В результате произошедших изменений в обществе постмодерна предметом исследования исторической науки все больше оказывается не историческое событие как таковое, а память (индивидуальная и групповая) о прошлом, сконцентрированная в сознании и бессознательных структурах сообщества: её содержание, способы передачи от поколения к поколению, её функционал.

Изучение коллективной памяти требует от историков принципиально других средств изучения, другой метафизической и этической позиции. Эта ситуация порождает ситуацию напряжения и конфликтности в историческом дискурсе. Известный немецкий историк и теоретик культуры Й. Рюзен утверждает, что «осмысление исторической репрезентации через категорию памяти может заставить историков почувствовать себя неуютно, поскольку оно очень легко выходит за рамки или даже отрицает те стратегии обращения к прошлому, которые конституируют исторические исследования как дисциплину или как «науку» и как профессиональное занятие историков» [16, с. 17].

В решении проблемы о соотношении исторической науки и коллективной памяти исследователи занимают разные позиции. Одни настаивают на несовпадении и противопоставлении истории и памяти. Этой позиции придерживаются М. Хальбвакс, Я. 
Ассман, Р. Коллингвуд, Х. Вельцер и др. Другая группа исследователей настаивает на том, что история основана на памяти. И, наконец, позицию французского историка П. Нора можно выделить в отдельную группу ответов, т. к. он, несмотря на то, что первоначально утверждает несовпадение истории и памяти, тем не менее пытается примирить коллективную память и историю.

Первым, кто актуализировал проблему соотношения исторической науки и коллективной памяти, был французский социолог М. Хальбвакс. «Историю, - пишет М. Хальбвакс, - можно представить, как универсальную память человеческого рода. Но универсальной памяти не существует. Носителем всякой коллективной памяти является группа, ограниченная в пространстве и времени» [5, с. 61]. Соответственно, без обращения к содержанию индивидуальной и коллективной памяти истории не существует, история основана на памяти. Однако изучение и анализ содержания памяти должны основываться на её мозаичности и плюралистичности. В отличие от истории память всегда многоголосна.

Хальбвакс утверждал, что история действует прямо противоположно коллективной памяти. Отношение коллективной памяти и истории М. Хальбвакс определяет как отношения последовательности. Когда прошлое перестает переживаться актуально, утрачиваются связи с лицами и местами, появляется история. «...История обычно начинается в тот момент, когда заканчивается традиция, когда затухает или распадается социальная память. Пока воспоминание продолжает существовать, нет необходимости фиксировать его письменно, да и вообще как-либо фиксировать. Поэтому потребность написать историю того или иного периода, общества и даже человека возникает только тогда, когда они уже ушли так далеко в прошлое, что у нас мало шансов найти вокруг себя многих свидетелей, сохраняющих о них какое-либо воспоминание» [5, с. 78].

Предметом исторической науки становятся события прошлого и их взаимосвязь. Реконструкция этих событий посредством обращения к достоверным источникам и извлечение из них необходимой информации являются первостепенной задачей для историка. Для него важно, что произошло, в чем причины произошедшего и каковы будут последствия? История обращается к событиям прошлого ради его знания, из любопытства, и это знание всегда избыточно, потому что историк пытается реконструировать наиболее полную картину происходящих событий. Первостепенную важность при реконструкции прошлого для историка представляет то, что было ценно и важно для современников этих событий, т. е. работа историка всегда ретроспективна. Прошлое для исторического исследования важнее настоящего. В отличие от исторической науки, «материал коллективной памяти - это не даты и факты, это уникальная психологическая и социальная атмосфера, привычки и характерные черты эпохи» [5, с. 79].

Память же вообще связана не столько с прошлым, сколько с настоящим. Она связывает прошлое и настоящее посредством повторения. Для неё реконструкция прошлого избирательна, она не стремится к полноте. Для памяти важно не само событие, а эмоционально окрашенный образ, в который носитель памяти вкладывает важный для него реальный или мифический смысл произошедшего. Таким образом, для памяти ценность представляет не то, как событие происходило, а то, как люди о нем помнят. Коллективная историческая память - это актуально востребованная в настоящем история, знание об общем прошлом, которое вызывает коллективное переживание и консолидирует общность или нацию.

История как наука ориентирована на факты и получение объективно-истинного знания о том, что и как происходило в прошлом. Но она не может остановиться только на уровне их бездумного накопления. По своей природе история является теоретиче- 
ским знанием, поэтому от накопления фактов она обязательно поднимается на уровень анализа, интерпретации произошедшего, выдвижения «рабочей гипотезы», объяснения и обобщения. Также необходимо отметить, что в истории присутствует сильно развитый субъективный фактор, поэтому историческое познание - это всегда сложное сочетание субъективного и объективного аспектов процесса познания. Познание прошлого в исторической науке не может быть прямым, оно всегда опосредовано источниками. Именно источники осуществляют функцию «моста» между прошлым и настоящим и дают историку информацию о жизни людей в предшествующие эпохи. Однако насколько объективную информацию могут дать источники? Всегда ли источник, с которым имеет дело историк, можно назвать объективным? И в каком контексте можно говорить об объективности по отношению к источнику?

Исторические источники можно назвать объективными в том смысле, что они несут на себе отпечаток эпохи, а субъективными - что люди, которые их пишут, вкладывают в них свои взгляды и убеждения, оценки, а иногда сознательно искажают произошедшее. Историк также не может быть полностью беспристрастным, хоть и стремится к этому, поскольку не свободен от ценностных установок своей эпохи и мировоззренческих позиций. Таким образом, достижение объективной истины в истории - непростая задача, которая решается посредством принципа гносеологического плюрализма. Историческая работа с фактами предполагает не только их регистрацию, но и отбор и интерпретацию. Для того чтобы приблизиться к объективности в исследовании, историк должен не только излагать свою позицию, но и упоминать о других интерпретациях событий, которые существуют в историческом дискурсе. Это является необходимым условием, вызванным спецификой предмета исторического исследования. Для получения истинного знания историк использует критическую оценку имеющихся источников. «Всякая история является критической по своей природе, и все историки всегда претендовали на то, чтобы разоблачить ложные мифологии своих предшественников» $[11$, с. 25].

Память, в отличие от исторического знания, субъективна и носит прагматическиприкладной характер. Она необходима в первую очередь для формирования национальной идентичности, поскольку «...память ценят там, где существуют проблемы с идентичностью» [17, с. 193]. Её консолидирующей силой выступает эмоциональная вовлеченность в некоторый общий коллективный опыт, сопричастность которому объединяет народ в нацию. Коллективная историческая память - фундаментальная способность человеческого общества, социальных групп, нации к воспроизводству прошлого. Коллективная память, с одной стороны, содержит устойчивую систему представлений о прошлом, бытующих в общественном сознании, с другой стороны, подвержена динамическим изменениям. Ей свойственна не столько рациональная, сколько эмоциональная оценка прошлого. С этих позиций историческая память делит события на «хорошие» и «плохие», ставит оценки по поведению в прошлом. И этим она радикально отличается от исторической науки.

Не всегда возможно обоснованно и однозначно развести историю и память, поскольку память и история связаны. Память, зафиксированная сначала в устном рассказе очевидцев, а потом записанная в целях сохранения, по мере ухода её живых носителей, трансформируется в историю, в архив и становится предметом пристального внимания со стороны историков. Историей становится то, чего уже нет в личном, живом опыте, а есть только в источниках. Помимо этого, историческое знание и память сближает общий функционал. И история, и коллективная память выполняют ориентирующую функцию, в том числе в морально-этическом плане. На основании знаний истории и опыта, зафиксированного в коллективной памяти, человек способен ориентироваться в 
той социально-исторической ситуации, в которой он оказывается. Часто он принимает решение, как поступить на основании этих знаний и представлений.

Одной из функций исторического знания является организация социальной памяти, социального сознания и социальных практик. История воздействует на коллективное и индивидуальное сознание, формирует мировоззрение. В функционал исторической науки входит воспитательная миссия, её задача воспитывать патриотизм. Исторические факты в школьном образовании используют как материал для воспитательных и нравственных уроков. История, почерпнутая из учебника, в современном обществе, видимо, составляет основу индивидуальной и коллективной исторической памяти. Вопрос о том, в какой степени школьное историческое образование играет роль каркаса, в который встраиваются впоследствии знания, почерпнутые из других областей, нуждается в дальнейшем изучении. В значительной мере школьные программы истории остаются событийными, а не «процессуальным». Пропуски, наличествующие в учебниках, - это прежде всего пропуски определенных событий. Конечно, замалчивания и пропуски объясняются методическими соображениями, но чаще - целевыми установками формирования национальной идентичности, в той ее части, которая опирается на знание о прошлом.

Одна из задач истории - это функция идентификации (например, национальной). В новоевропейском проекте народного образования на первом плане стоит формирование национальной общности и привязанности к своему прошлому. Для решения этой задачи в XIX в. в развитых странах формируются институты, регламентирующие и контролирующие содержание учебников по истории и практику преподавания этого предмета. Школьное историческое образование неизбежно представляет собой «краткий курс», вопрос в том, за счет чего достигается эта краткость. И цель, которая преследуется при этом, носит не познавательный, а идеологический характер: обучение истории, воспитывающей чувство гордости за национальное прошлое. «Политики любят делать акцент на интегрирующей функции истории. Они надеются, что активизация исторического сознания позволит нам «вновь обрести и упрочить нашу историческую идентичность» [18, с. 540-541].

Всякой политической идеологии нужна своя история и, следовательно, своя «сконструированная» для данной общности коллективная память, поэтому в социуме всегда сосуществуют несколько «конкурирующих» историй. Они присутствуют в различных социальных группах, в том числе маргинальных. «В то же время неустранимость из социального сознания иных, чем доминирующих, версий тех или иных событий, сосуществование нескольких «образов» прошлого свидетельствуют о том, что в отношении к прошлому проявляется своего рода объяснительный плюрализм» [11, с. 18].

Официальной версии истории, доминирующей в данном обществе, всегда противостоит «контрпамять» маргинальных социальных групп. История как наука представляет собой особую систему работы с историческими источниками и документами. В своем стремлении к объективности и беспристрастности история как наука противостоит всем видам памяти. Миссия коллективной памяти по отношению к исторической науке заключается в том, что память обогащает историю ценностными ориентирами, высвечивает наиболее значимые для коллективного сознания события прошлого, история же призвана скорректировать комплекс имеющихся воспоминаний, критически отрефлексировать их. «...Изучение памяти - это bona fide интеллектуальное упражнение, позволяющее ученым ответить на самые интересные вопросы философского наследия прошлого столетия. В частности, через понятие памяти мы можем продемонстрировать немногим оставшимся постмодернистским критикам, как в действительности работают репрезентации и чем можно объяснить их силу» $[17$, с. 182]. 
Механизм взаимоотношений коллективной памяти и исторической науки можно определить через принцип комплементарности. В соответствии с этим принципом память и история, в процессе взаимодействия, могут выполнять свои функции только взаимно дополняя друг друга по содержанию. В то же время они остаются различными по своей сущности. Память и история реконструируют разные аспекты прошлого: история стремится к объективности посредством исторического критицизма и верификации, коллективная память фиксирует значимые для коллективного сознания исторические события и формирует ценностное отношение к прошлому.

Начиная с XIX в. в исторической науке основополагающим понятием было понятие «историческое сознание». Оно определялось как важнейшая характеристика исторической науки общества модерна. Однако это понятие не имело четкой дефиниции, и на протяжении XX в. в социологии разрабатываются, а впоследствии заимствуются историками, концепты «представления о прошлом», «менталитет» и «знания о прошлом». Достаточно долго историки обходились без понятия «историческая память», однако потребность в изучении содержаний коллективного опыта, оставившего следы в памяти, была, поэтому историки использовали метафоры, такие как «память нации», «память немцев» и др. В конце XX столетия наряду с понятиями «историческое сознание», «историческое знание» и «представления о прошлом» в исторических исследованиях все чаще появляется концепт «исторической памяти».

Некоторые исследователи считают, что в современной историографии новый концепт «исторической памяти» в определенной степени начинает подменять понятие «историческое сознание», столь привычное для исторических рефлексий в отношении ментальности современного человека. В тех же случаях, когда от понятия «историческое сознание» не отказываются, возникают серьезные трудности с разведением этих категорий. Впрочем, с концептуализацией самой «исторической памяти» тоже не все так просто.

В современных исследованиях существует множество определений исторического сознания. Например, отечественный историк М.А. Барг определяет историческое сознание как «...форму общественного сознания, в которой совмещены все три модуса исторического времени - прошлое, настоящее и будущее» [19, с. 29]. Он считает, что историческое сознание является мировоззренческой характеристикой для культуры любой эпохи. Поскольку историческое сознание представляется как особая структура, в ней фиксируются наиболее значимые для каждой эпохи представления о мире, осмысление исторических событий и места человека в истории. В историческом сознании совмещаются и учитываются все три временные проекции в существовании человеческого общества: настоящее, прошлое и будущее, поэтому оно может выступать в качестве онтологического объяснения его существования.

Историческое сознание - это рационально-рефлексивное сознание и отношение человека и социума в целом к миру. В связи с этим одной из главных функций исторического сознания в обществе является способность создавать на теоретическом познавательном уровне пространственно-временную ориентацию в истории, которая обеспечивает возможность для познания своего исторического прошлого и осмысления его причинного-следственных связей с настоящим и будущим. Эти рефлексивные акты, направленные на исторический опыт, позволяют нации познавать свою уникальность. Размышление над опытом прошлого является основанием и условием построения для каждой общности своей идентичности. Недостаток рефлексии может привести к разрушению коллективной идентичности и отсутствию национальной идеи, которые приведут, в свою очередь, к полной разобщенности в социуме. 
В структуре исторического сознания принято выделять три уровня. Первый из них представляет собой обыденное сознание и знание о прошлом. Это уровень обыденных знаний, чаще всего не имеющих рефлексивного характера и, как правило, не осознаваемые основной частью общества. Этот уровень символизирует непосредственную встречу человека с историей, которая происходит посредством соприкосновения с воспоминаниями людей предшествующих поколений, соблюдение традиций в повседневной практике, изучение исторической литературы и посещение памятных мест и т. д. Существенной характеристикой, которая отличает этот уровень от двух других, является бессистемность и хаотичность знаний и представлений о прошлом. Однако именно этот уровень наиболее приближен к понятию «коллективная историческая память». Основным источником этих знаний является коммуникативный обмен информацией, фольклор и устные предания, художественная литература, национальные памятники и символы. Во всех этих источниках содержатся элементы социальной/коллективной памяти, которая сохраняет материальные и духовные следы мира прошлого. Коллективная историческая память создает особую коммуникативную среду, сопричастность к которой позволяет основной массе людей усваивать в повседневном опыте знания о своем историческом прошлом. Таким образом, коллективная память порождает содержание обыденного уровня исторического сознания.

Второй уровень - это собственно историческое сознание, которое представляет собой не хаотичный набор представлений о прошлом, а уже систему знаний. Он формируется системой образования и культурными предпочтениями его носителей: художественной литературой, кино, театром, музеем и средствами массовой информации. Формирование современного исторического сознания анализируется в превосходной работе М. Ферро [20]. На материалах школьных учебников начальных классов он исследует, как в раннем возрасте закладываются стереотипы обыденных исторических представлений. Французскому историку удалось очень убедительно показать, что в разных странах базовое историческое образование формируется на основе разных и, главное, противоречащих друг другу исторических знаний. И цель, которая преследуется при этом, носит не познавательный, а идеологический характер - обучение истории, воспитывающей чувство гордости за национальное прошлое.

И, наконец, третий уровень исторического сознания представляет собой собственно теоретическое мышление исторического процесса. Этот уровень включает в себя категориально-понятийный аппарат исторической науки и попытки объяснения исторических событий в диалектических противоречиях их развития с применением методов и принципов, благодаря которым оказывается возможным получение объективного знания. Носителями этого уровня являются не простые обыватели и социальные группы, а профессиональное историческое сообщество. На этом уровне историческое сознание сводится к рациональному познанию и как рациональное оно определяется такими чертами, как доказательность, системность и критическая рефлексия.

И память, и историческое сознание являются конструкцией и репрезентацией содержаний исторического опыта. Историческое сознание производит отбор и переупорядочивание фактов, память осуществляет эту же деятельность по отношению к воспоминаниям о событиях прошлого. В коллективной памяти, как и в историческом сознании, актуальное настоящее влияет на реконструкцию прошлых событий. Память, сохраняя образ прошлого, трансформирует его. Историческое сознание также не свободно от радикальных изменений образов прошлого и т. д. Рассматривая коллективную историческую память и историческое сознание как «динамичные системы, представляющие собой не только непосредственные знания о прошлом, но и постоянные про- 
цессы их реконфигурации, зависящие от контекста социальной среды и деятельности, полей и средств передачи памяти ... было бы ошибкой однозначно разводить социальную память и историческое сознание по линии «рациональное-иррациональное», поскольку в них присутствуют, хотя и в разной мере, и то, и другое [21, с. 199].

Таким образом, в современных исследованиях можно констатировать устойчивое соотношение понятий «историческое сознание» и «коллективная историческая память». Это не вызывает возражений, однако будет неверно сводить историческое сознание к исторической памяти и использовать их как синонимы.

Историческое сознание, как и историческая память, направлено на осмысление травмы прошлого, значимость которой, по меткому замечанию американского историка Д. Ла Капры, «...как раз в том, что она подрывает опыт и не может быть в него интегрирована» [22, с. 107]. Травматические события должны не просто артикулироваться (это осуществляет коллективная память), а «прорабатываться». «...Коллективная травма - это комплекс психологических ощущений, возникающий у очевидцев или участников определенного трагического события и являющийся общим, но при этом в полной мере не передаваемым опытом не просто выживания, но и последующего переживания данной ситуации» [23, с. 70]. «Проработка» травмирующих коллективного субъекта воспоминаний представляет собой процесс рационализации прошлого, который ограничивает повторяемость воспоминаний и осуществляет переход от меланхолии к трауру.

\section{Выводы}

1. Коллективная историческая память и идеология понимаются как социальные конструкты с элементом деконструкции. В отличие от идеологии, которая представляет собой относительно устойчивый и долговременный конструкт, память нестабильна, изменчива, способна к самоорганизации воспоминаний о прошлом. И идеология, и память искажают память о прошлом. Однако механизм этих искажений различный. Несмотря на то, что коллективная память формируется в том числе официальной идеологией и системой образования, по своему содержанию она чаще всего не совпадает с тем, что ей принудительно навязывается извне, поэтому между коллективной памятью и официальной идеологией может иметь место противоречие, переходящее в конфликт.

2. Механизм взаимоотношений коллективной памяти и исторической науки можно определить через принцип комплементарности. В соответствии с этим принципом память и история, в процессе взаимодействия, могут выполнять свои функции, только взаимно дополняя друг друга по содержанию. В то же время они остаются различными по своей сущности. Память и история реконструируют разные аспекты прошлого: история стремится к объективности посредством исторического критицизма и верификации, память формирует ценностное отношение к прошлому.

3. Основными причинами, по которым оказывается невозможно использовать понятие «коллективная историческая память» в качестве синонима «исторического сознания», являются его существенные отличия. Историческое сознание является одновременно способом фиксации коллективной исторической памяти и теоретическим мышлением, направленным на работу с фактическим материалом. В качестве научного метода оно ориентировано на объективность и истинность в процессе познания, тогда как содержание исторической памяти не всегда возможно проверить на достоверность. Историческое сознание и память отличаются способами интерпретации и критериями отбора исторически значимых событий. Специфика исторического сознания и его существенное отличие от коллективной исторической памяти заключаются в том, что оно осуществляет рационализацию процессов обращения к прошлому. 
4. Понятие «коллективная историческая память» обладает теоретической ценностью, поскольку описывает уникальный феномен - фундаментальную способность социальных групп и нации в целом сохранять и реконструировать воспоминания о совместном историческом опыте. Понятие «коллективная историческая память» - эвристически значимый концепт, поскольку является аналитическим инструментом, позволяющим объяснить наличие или отсутствие национальной идеи, оценить степень консолидации и самоидентификации той или иной общности и в совершенно новом ракурсе репрезентировать структуру социальных представлений о прошлом в разных сообществах.

\section{СПИСОК ЛИТЕРАТУРЫ}

1. Rieff D. In praise of forgetting: historical memory and its ironies. - New Haven, CT: Yale University Press, 2016. $-160 \mathrm{p}$.

2. Ассман Я. Культурная память: письмо, память о прошлом и политическая идентичность в высоких культурах древности. - М.: Языки славянской культуры, 2004. -368 с.

3. Зонтаг С. Когда мы смотрим на боль других. URL: http://index.org.ru/journal/22/zontag22.html (дата обращения 01.06.2020).

4. Ассман А. Длинная тень прошлого: Мемориальная культура и историческая политика. - М.: Новое литературное обозрение, 2014. - 328 с.

5. Halbwachs M. La memoire collective. - P.: Presses Universitaires de France, 1967. - 204 p.

6. Олик Д.К. Коллективная память: две культуры // Историческая экспертиза. - 2018. - № 4 (17). C. 22-50.

7. Рубцов А.В. Иллюзии деидеологизации // Философия и идеология: от Маркса до постмодерна / отв. ред. А.А. Гусейнов, А.В. Рубцов; сост. А.В. Рубцов. - М.: Прогресс-Традиция, 2018.- С. 98-129.

8. Щербакова Е.В. Сознательное и бессознательное в идеологии // Вопросы философии. - 2019. № 12. - C. 31-40.

9. Альтюссер Л. Марксизм и гуманизм // За Маркса. - М.: Праксис, 2006. - С. 311-343.

10. Жижек С. Возвышенный объект идеологии. - М.: Художественный журнал, 1999. -236 с.

11. Нора П. Проблематика мест памяти // Франция-память. - СПб: Изд-во Санкт-Петербургского университета, 1999. - С. 17-50.

12. Мэрридейл К. Каменная ночь. Смерть и память в России XX века. - М.: ACT: CORPUS, 2019. - 512 c.

13. Рикёр П. Память. История. Забвение. - М.: Изд-во гуманитарной литературы, 2004. - 728 с.

14. Лекторский В.А. Неизбежность идеологии // Философия и идеология: от Маркса до постмодерна / отв. ред. А.А. Гусейнов, А.В. Рубцов; сост. А.В. Рубцов. - М.: Прогресс-Традиция, 2018. - С. 180-189.

15. Савельева И.М., Полетаев А.В. «Историческая память»: к вопросу о границах понятия // Феномен прошлого / под ред. И.М. Савельева, А.В. Полетаев. - М.: ГУ-ВШЭ, 2005. - С. 170-220.

16. Рюзен Й. Утрачивая последовательность истории (некоторые аспекты исторической науки на перекрестке модернизма, постмодернизма и дискуссии о памяти) // Диалог со временем. Альманах интеллектуальной истории. - 2001. - Вып. 7. - С. 8-26.

17. Kansteiner W. Finding meaning in memory: a methodological critique of collective memory studies // History and Theory. - 2002. - V. 41. - № 2 - P. 179-197.

18. Ассман А. Забвение истории - одержимость историей. - М.: Новое литературное обозрение, 2019. $-552 \mathrm{c}$.

19. Барг М.А. Историческое сознание как проблема историографии // Вопросы истории. - 1982. № 12 . - C. $28-35$.

20. Ферро М. Как рассказывают историю детям в разных странах мира. - М.: Книжный Клуб 36.6, 2010. $-461 \mathrm{c}$

21. Линченко А.А. Целостность исторического сознания: вопросы истории и методологии. - Воронеж: Воронежский государственный педагогический университет, 2014. - 248 с.

22. LaCapra D. History and reading: Tocqueville, Foucault, French studies. - Toronto: University of Toronto Press Inc., 2000. -235 p.

23. Аникин Д.А., Головашина О.В. Травмы культурной памяти: концептуальный анализ и методологические основания исследования // Вестник Томского государственного университета. - 2017. № 425. - C. 66-73.

Поступила 03.06.2020 г. 
UDC 316.4.051.62

\title{
COLLECTIVE HISTORICAL MEMORY: THE BASIS FOR DEFINING THE CONCEPT AND ITS ROLE IN MODERN CULTURE
}

\author{
Nataliya S. Kornyushchenko-Ermolaeva, \\ nskorn@yandex.ru
}

\begin{abstract}
Tomsk State University of Control Systems and Radioelectronics, 40, Lenin avenue, Tomsk, 634050, Russia
\end{abstract}

\begin{abstract}
Nataliya S. Kornyushchenko-Ermolaeva, senior lecturer, Tomsk State University of Control Systems and
\end{abstract} Radioelectronics.

Relevance of the research. The concept of «collective historical memory» causes many controversies related to its content and use. The article is devoted to the problem of using the concept of «collective historical memory» and the analysis of the reasons for its allocation as a concept that has its own semantic content and essential features. The article examines its role and place in modern culture. The main aim of this article is to substantiate the semantic content and essential features of the concept of "collective historical memory», to show that it can be used as an independent concept. As a semantic concept, this concept does not replace others, it has a theoretical and heuristic value. Collective historical memory is the mental ability of social groups and the nation as a whole to symbolically reconstruct significant historical events in the process of collective memorization and oblivion, giving them a certain value interpretation. The article identifies significant differences between collective historical memory and ideology, defines the principle of complementarity as a principle describing the specifics of interaction between collective historical memory and historical science, indicates significant differences in the content of the concepts of «historical consciousness» and "collective historical memory", and identifies the reasons why these concepts can not be synonymous. Methods. Theoretical and methodological basis of research are the concept of memory as a social and cultural phenomenon (M. Halbwachs, P. Nora, P. Ricker, A. Assman et al.), research on the relationship of collective historical memory with ideology, historical science and historical consciousness (A. Althusser, S. Zizek, A.V. Rubtsov, H. Welzer, J. K. Olik, etc.) Conclusions. As a result of this analysis, the heuristic value of the concept of «collective historical memory» is justified. The author reveals its semantic content and internal contradictions that lead to terminological confusion in the socio-philosophical scientific discourse. The concept of "collective historical memory» has theoretical value, since it describes a unique phenomenon - the fundamental ability of social groups and the nation as a whole to preserve and reconstruct memories of shared historical experiences.

Key words: Collective historical memory, political ideology, history, historical consciousness, national identity, official memory.

\section{REFERENCES}

1. Rieff D. In praise of forgetting: historical memory and its ironies. New Haven, CT, Yale University Press, 2016. $160 \mathrm{p}$.

2. Assman Ya. Kulturnaya pamyat: pismo, pamyat o proshlom $i$ politicheskaya identichnost $v$ vysokikh kulturakh drevnosti [Culturae memoria: scribens, memoria et politica identitatem in altum culturis antiquis]. Moscow, Yazyki slavyanskoy kultury Publ., 2004. 368 p.

3. Zontag S. Kogda my smotrim na bol drugikh [When we look at the pain of others]. Available at: http://index.org.ru/journal/22/zontag22.html (accessed 1 June 2020).

4. Assman A. Dlinnaya ten proshlogo: memorialnaya kultura i istoricheskaya politika [The long shadow of the past: memorial culture and historical politics]. Moscow, Novoe literaturnoe obozrenie Publ., 2014. $328 \mathrm{p}$. 
5. Halbwachs M. La memoire collective. Paris, Presses Universitaires de France, 1967. 204 p.

6. Olik D.K. Kollektivnaya pamyat: dve kultury [Collective memory: the two cultures]. Istoricheskaya ekspertiza, 2018, no. 4 (17), pp. 22-50.

7. Rubtsov A.V. Illyuzii deideologizatsii [Illusions of deideologization]. Filosofiya i ideologiya: ot Marksa do postmoderna [Philosophy and ideology: from Marx to postmodern]. Eds. A.A. Guseynov, A.V. Rubtsov; Moscow, Progress-Traditsiya Publ., 2018. pp. 98-129.

8. Shcherbakova E.V. Soznatelnoe i bessoznatelnoe v ideologii [Conscious and unconscious in ideology]. Voprosy filosofii, 2019, no. 12, pp. 31-40.

9. Altyusser L. Marksizm i gumanizm [Marxism and humanism]. Za Marksa [For Marx]. Moscow, Praksis Publ., 2006. pp. 311-343.

10. Zhizhek S. Vozvyshenny obyekt ideologii [Sublime object of ideology]. Moscow, Khudozhestvenny zhurnal Publ., 1999. 236 p.

11. Nora P. Problematika mest pamyati [Problems of places of memory]. Frantsiya-pamyat [France-memory]. St-Petersburg, Sankt-Peterburg universitet Publ., 1999. pp. 17-50.

12. Merrideyl K. Kamennaya noch. Smert i pamyat v Rossii XX veka [Stone Night. Death and memory in Russia of the twentieth century]. Moscow, AST, CORPUS Publ., 2019. 512 p.

13. Rikor P. Pamyat. Istoriya. Zabvenie [Memory. History. Oblivion]. Moscow, Humanitarian literatures Publ. house, 2004. 728 p.

14. Lektorskiy V.A. Neizbezhnost ideologii [The inevitability of ideology]. Filosofiya i ideologiya: ot Marksa do postmoderna [Philosophy and ideology: from Marx to postmodern]. Eds. A.A. Guseynov, A.V. Rubtsov; Moscow, Progress-Traditsiya Publ., 2018. pp. 180-189.

15. Saveleva I.M., Poletaev A.V. «Istoricheskaya pamyat»: k voprosu o granitsakh ponyatiya [«Historical memory»: to the question of the boundaries of the concept]. Fenomen proshlogo [Phenomenon of the past]. Eds. I.M. Saveleva, A.V. Poletaev. Moscow, GU-HSE Publ., 2005. pp. 170-220.

16. Ryuzen Y. Utrachivaya posledovatelnost istorii (nekotorye aspekty istoricheskoy nauki na perekrestke modernizma, postmodernizma i diskussii o pamyati) [Losing the sequence of history (some aspects of historical science at the crossroads of modernism, postmodernism and discussion of memory)]. Dialog so vremenem. Almanakh intellektualnoy istorii, 2001, Iss. 7, pp. 8-26.

17. Kansteiner W. Finding meaning in memory: a methodological critique of collective memory studies. History and Theory, 2002, vol. 41, no. 2, pp. 179-197.

18. Assman A. Zabvenie istorii - oderzhimost istoriey [Oblivion of history - obsession with history]. Moscow, Novoe literaturnoe obozrenie Publ., 2019. 552 p.

19. Barg M.A. Istoricheskoe soznanie kak problema istoriografii [Historical consciousness as a problem of historiography]. Voprosy istorii, 1982, no. 12, pp. 28-35.

20. Ferro M. Kak rasskazyvayut istoriyu detyam v raznykh stranakh mira [How the history is told to children around the world]. Moscow, Knizhnyy Klub 36.6 Publ., 2010. 461 p.

21. Linchenko A.A. Tselostnost istoricheskogo soznaniya: voprosy istorii i metodologii [Integrity of historical consciousness: issues of history and methodology]. Voronezh, Voronezh State Pedagogical University Publ., 2014. 248 p.

22. LaCapra D. History and reading: tocqueville, foucault, french studies. Toronto, University of Toronto Press Inc., 2000. 235 p.

23. Anikin D.A., Golovashina O.V. Travmy kulturnoy pamyati: kontseptualny analiz i metodologicheskie osnovaniya issledovaniya [Trauma of cultural memory: conceptual analysis and methodological foundations of the study]. Vestnik Tomskogo gosudarstvennogo universiteta, 2017, no. 425, pp. 66-73.

Received: 3 June 2020. 